УДК 631.4

\title{
SOILS IN THE MODERN CHANGING WORLD
}

\author{
Stepan Pozniak \\ Ivan Franko National University of Lviv, \\ P. Doroshenko Str., 41, UA-79000 Lviv, Ukraine
}

The most common known about biological and ecological function of soils is their fertility, or in a broader sense - the biological productivity of soil. Despite the very small thickness of soil cover on the Earth, which is just a thin layer on the surface, this layer is the most biologically productive part of the biosphere.

It is proved that the most important impact soils provided on human health, especially because of anthropogenic pollution of soils. Particularly one of the most discussed is the problem of anthropogenic pollution of soils in urban areas near major highways, in areas of mining, including oil, gas, non-ferrous metals, building materials, as well as soil pollution by radioactive elements and pesticides.

Key words: soils, soil science, soil degradation, soil pathology, healthy of soil.

Science is need to be estimated on the subject of its place in the overall system of scientific knowledge, to clarify the role it plays in the scientific, industrial and social human life. At the beginning of XXI century this need arose repeatedly in the soil science. It was caused by intensification of soil cover degradation, pollution of the biosphere, the growing threat of the global ecological crisis. There is a need to change consumer attitudes to soil as one of the most important part in biosphere. These are not just words, but a reality of our time.

The specificity and importance of each science are determined by features of the research object. The main feature of soil as a natural body is its organic-mineral composition and inseparable relationship in time and geographical space with the evolution of the whole nature on the Earth. This requires the involvement of a wide range of research methods to study soils and its genesis, geography, structure, properties and functions.

It is obvious the uniqueness of the soil as a place for life because it provide home to about $92 \%$ of all known species of plants and animals, which gives reason to call soils as repository of genetic diversity of life on our planet. It is hard to imagine that in one gram of soil can contain up to several billion bacterial cells, hundred meters of fungal hyphae, thousands simplest single-celled animals, many thousands of meters of fine roots and small roots of plants [5, p. 23].

The problem of biodiversity conservation, which attracts more and more attention of the scientific community, directly relates to the soil. The United Nations Convention on Biological Diversity (1992) emphasized that this problem is a common and very important for mankind. There is very important formulation of the provisions of the Convention in terms of soil science - "... the basic condition for the conservation of biodiversity is in situ conservation of ecosystems and natural habitats, maintain and restore viable populations of species in their natural environment". Between soils and organisms that inhabit soils, there is a close connection and interdependence. The unique species groups of plants, animals and

(C) Pozniak S., 2015 
microorganisms belong to each soil type. It means that the biodiversity problem cannot be solved without soil conservation in national parks, natural reserves, botanical gardens and other protected areas [9].

Soils provide the link for biological and geological circulation of substances on Earth. There is a two-way process of degradation and synthesis of substances formed by photosynthesis and restoration of existing chemical elements into the new composition of living matter. The total mass involved into biological cycle of mineral elements is several times higher than their value in the total ionic annual runoff into the ocean [3, p. 320].

The most common known biological and ecological function of soils is their fertility, or in a broader sense - the biological productivity of soil. Despite the very small thickness of soil cover of the Earth, which is just a thin layer on the surface, this "layer" is the most biologically productive part of the biosphere. Biomass linked with soil, is $99.8 \%$ of the total biomass on Earth. Annual biological productivity of terrestrial plant groups significantly exceeds the oceans. Weight of food received by man on land resulting from the use of soils is $93 \%$ of the mass food on Earth. Only those data enough to witness the irreplaceable value function of soil fertility, biological functions of its performance for the life of the people, for all life on Earth.

One of the most important soil impacts is its footprint on human health, especially because of anthropogenic contamination of soils. It has long been observed that there is a direct link between the specificity of the chemical composition of soil in some areas and the presence of regional endemic diseases of humans and animals. It is well known thyroid disease due to lack of iodine in acid podzolic soils. Particularly acute and understudied is the problem of anthropogenic contamination of soils in urban areas, near major highways, in areas of mining, including oil, gas, non-ferrous metals, building materials, as well as soil contamination with radioactive elements and pesticides. There are cases of long-term soil microbial contamination (tetanus, botulism, anthrax). Become common allergic disease in cities caused by microscopic soil fungi. There is the concept of "common ground" as a necessary condition for human health. Pollution, soil degradation and destruction are known as "pathology soil" [6, p. 18]. Pathology soil poses a threat to the whole future destiny of mankind, so should be overcome.

In fact, the soil cover as the global natural system is closely interrelated within the human history. These relationships are very different; they began to emerge in the human ancient time. However, such relations appeared during the time of agriculture development and especially during the process of formation the ancient agricultural civilizations. Moreover, due to soil fertility, the earliest civilizations arose on alluvial soils in the valleys of the big rivers of the southern countries - Nile in Egypt, the Tigris and Euphrates in Mesopotamia, the Ganges in India, the Yangtze and the Huanhe in China, the Amudaria and Syrdaria in Central Asia etc.

In Ukraine, the development of agriculture is associated with fertile black soils. It was "Tripoli culture" - Eneolithic archaeological culture (4-3 millennium BC). People from that culture developed agriculture, hunting and cattle-breeding.

Early agriculture hotspots were mountain countries from tropical and subtropical zones of the Earth. Later, the population increasing occurred fast migration and farming spread around the planet. People settled the less fertile soils of temperate and even northern latitudes, which demanded more efforts, knowledge and skills of farmers. Rapid and uncontrolled ploughing of large areas was increasingly accompanied by processes of water and wind erosion, 
swamping and salinization. In the second half of the nineteenth century, and especially in the twentieth century, these processes have reached global dimensions and began strongly affect on biosphere level and human life in many countries. The polluted lands, exhausted and destroyed soils significally increased during the last century.

At the end of XX century, these environmental problems caused a process lead by several international organizations the analysis of soil and land resources in the world. It was found that the area of cultivable land on Earth is 3 billion 278 million hectares, or $22 \%$ of the total land area. High- and middle productive soils (already fully under cultivation) cover only $9 \%$ of the Earth's land. The remaining $78 \%$ of the lands is not appropriate for intensive agriculture by climatic, orographic or other natural conditions. Nowadays, the arable land covers 1.5 billion hectares; the rest is non-arable land, unproductive soils that require high costs for their development. These are the red acid and alkaline feralitic soils and soils of dry tropical and subtropical savanna with plenty of alkaline and saline soils.

Moreover, the loss of soil fertile is actual for today. Every year there is a process of removing the agricultural land to the land category of other economic purposes (about 8 million hectares) and land lost caused by soil degradation (about 7 million hectares). At the end of XX century the 15 million hectares of productive land were lost annually [1, p. 314].

The largest area of degraded soils is located in the countries and regions with ancient agriculture. It was caused by uncontrolled land use for centuries. Global process of degradation and destruction of soil called "silent crisis of the world". Among soil degradation processes in the world we can select: water erosion (56\%), wind erosion (28\%), chemical degradation (12\%) and $4 \%$ is physical degradation.

Degradation is almost inevitable companion of mankind for centuries. Obviously there are differences in the degradation process and they mainly depend on the level of society, understanding of the patterns of soil formation, economic development etc. To prevent land degradation and action required consistent, coordinated, systematic actions of the government and all sectors of society. Moreover, media should contribute to soil protection and sustainable use [7, p. 11].

In Ukraine, soil erosion is one of the most significant factors caused reducing productivity of land resources, increasing degradation of agricultural landscapes. The total area of agricultural land that suffered from the damaging effects of water erosion is 13.4 million hectares (10.6 million hectares $(32 \%)$ of arable land).

The deflated soils in Ukraine covered about 155.6 thousand hectares, represented by medium and strong deflated soils. The saline deflated soils covered almost 301.4 thousand hectares. This category includes salt marshes, medium and strong hydromorphic soils, secondary-automorphic soils of the irrigated areas. The saline irrigated soils covered over 200 thousand hectares. Wetlands and marshy soils covered an area of 590.0 thousand hectares. Total area of drained land in Ukraine is about 3,12 million hectares.

Analysis of data on soil contamination by various toxic compounds shows that $20 \%$ of the country is in poor condition; 8.4 million hectares contaminated with radionuclides.

Over the past year a new extremely important issue appeared in Ukraine the degradation, destruction and destroying of soils in Donetsk and Lugansk regions due to the war. Thousands of hectares of highly productive soils degraded during this terrible war. Military degradation causes the destruction of soil cover, breach of morphological structure profile, mixing of the genetic horizons, changing the composition and properties of soils, the unusual inclusions appears in soil profile - alien bodies (shrapnel shells, mines, missiles, 
cartridges, etc.), intensely compacted soil by heavy military machines. On the ground many destructive forms caused by rupture of mines, grenades, construction trenches, dugouts were appeared.

The process of land reclamation in Donbass region should start with soil and geographical surveys and mapping of soil cover areas affected by military degradation, complex studies of the properties of disturbed soils, its agroecological evaluation etc. This is very important task and needs to be urgently addressed. Solving the issued problems will significantly contribute to the revival of Donbass region.

We can conclude that state of soil resources Ukraine provokes concern not only scientists, but also the majority of our population. It is vital to create an exemplary level of use and management of soil resources, providing primarily long-term study of strategy use, restoration and management of soil resources and comprehensive monitoring of their functions in Ukraine. It is extremely important to pass and implement the law of Ukraine "Soils and its fertility" [8].

Despite the authoritative declarations and measures of soil protection on international and national levels, the degradation of soil cover still exists. There are many reasons, including financial, economic, administrative caused such extensive soil use, but not the last role play the lack of understanding of the reality of the global threat posed by the process of land degradation and provoke disruption of biosphere sustainability.

\section{REFERENCES}

1. Dobrovolsky, G. V. (2003). The quiet crisis of the planet. MM: Academa, 396 pp. (in Russian).

2. Dobrovolsky, G. V., \& Nikitin, E. D. (2000). Soil protection as a component of the biosphere. Moscow: Nauka, 185 pp. (in Russian).

3. Dobrovolsky, G. V. (1997). Fundamentals of biochemistry. Vestnik RAN, 3, 313-319 (in Russian).

4. Dobrovolsky, G. V., \& Nikitin, E. D. (2006). Soil ecology. Moscow: Published in University Press, 362 pp. (in Russian).

5. Dobrovolsky, G. V. (2012). Soil cover as the layer with high concentrations and variety of life on Earth. Soil in the biosphere and human life. Moscow, 20-34 (in Russian).

6. Kovda, V. A. (1989). The pathology of soils and biosphere on the planet. Pushchino: Preprint, 35 pp. (in Russian).

7. Medvedev, V. V. (2002). Soils and Ukrainian society in the twentieth century. Agricultural Chemistry and Soil Science. Special Issue. Kharkiv, 7-14 (in Ukrainian).

8. Pozniak, S. P. (2014). Problematic and fundamental basis of soil science. Geopolitics and ecogeodynamics of regions. Scientific magazine, 10(1). Simferopol, 86-91 (in Ukrainian).

9. Convention on Biological Diversity, available at: www.cbd.int.

Стаття: надійшла до редакиії 23.07.2015 доопраиьована 08.09.2015 прийнята до друку 22.09.2015 


\section{ГРУНТИ В СУЧАСНОМУ МІНЛИВОМУ СВІТІ}

\section{Степан Позняк}

Львівський національний університет імені Івана Франка, вул. П. Дороченка, 41, 79000, м. Львів, Україна

Найвідомішою загальною біологічною і екологічною функцією грунтів є їхня родючість, або в ширшому розумінні - біологічна продуктивність грунтів. Незважаючи на дуже малу товщину грунтового покриву Землі, який є буквально тоненькою плівкою на іiї поверхні, власне ця “плівка" - найбільш біологічно продуктивна частина біосфери.

Щораз важливішого значення надають впливу грунту на здоров'я людини, особливо через антропогенне забруднення грунтів. Дуже гострою i недостатньо вивченою $\epsilon$ проблема антропогенного забруднення грунтів у містах, біля великих транспортних магістралей, у районах видобування корисних копалин, зокрема, нафти, газу, руд кольорових металів, будівельних матеріалів, не кажучи вже про забруднення грунтів радіоактивними елементами і пестицидами.

Ключові слова: грунти, грунтознавство, деградація грунтів, патологія грунтів, здоровий грунт. 